\title{
Application of Linear Programming in Modeling the Allocation of Buses to Routes in a Transport Service Authority
}

\author{
Ngutor Nyor ${ }^{1, *}$, Omolehin J.O. ${ }^{2}$, Rauf K. ${ }^{3}$ \\ ${ }^{1}$ Department of Mathematics/Statistics, Federal University of Technology Minna, Minna, Nigeria \\ ${ }^{2}$ Department of Mathematics, Federal University Lokoja, Kogi State, Nigeria \\ ${ }^{3}$ Department of Mathematics, University of Ilorin, Ilorin, Nigeria \\ *Corresponding Author: ngutornyor@yahoo.com
}

Copyright (C) 2014 Horizon Research Publishing All rights reserved.

\begin{abstract}
The objective of the study was to allocate the available buses of the transport authority to the authority's service intra and inter states routes in a manner that will yield optimum profit, taking all the constraints into consideration. The problem was modeled using Linear Programming (LP) and the TORA - computer software result yielded a maximum objective value of N897, 214 per day after 20 iterations, which is a better result compared to the current intuitive schedule by the authority that yields N766, 046 per day.
\end{abstract}

Keywords NSTA, TORA, Linear Programming, Transport Service, Bus(Es), Route(S), Objective Value

\section{Introduction}

Niger State Transport Authority (NSTA) is a state-own transport service operator in Minner, Niger state, Nigeria with the following seven commuting services
i. Inter State services
ii. Intra State services
iii. City service within Minna municipal, Bida and Kontagora towns
iv. Towing, Haulage and Hire services to all parts of Nigeria
v. Ferry services from Rofia across to Zamare in Kebbi State and from Shiroro across to Lakpama, in Niger State

vi. Passenger Boat service from kofa to kabo in Suleja area council

vii. Civil servants and students Bus services within Minna municipal (NSTA, n.d)

However, this study was limited to the first two services inter and intra state services due to interest and inadequate finance. These routes are as follows:

\author{
Inter States Routes \\ MINNA-ILORIN \\ MINNA-LAGOS \\ MINNA-KADUNA \\ MINNA-KANO \\ MINNA-MAKURDI \\ MINNA-JOS \\ MINNA-BAUCHI \\ MINNA-SOKOTO \\ MINNA-ZAMFARA \\ MINNA-KATSINA \\ Intra State Routes \\ MINNA-BIDA \\ MINNA-MOKWA \\ MINNA-NEW BUSA \\ MINNA-KTAGORA \\ MINNA-KAGARA \\ MINNA-WUSHISHI \\ MINNA-SULEJA \\ MINNA-SERKI PAWA \\ MINNA-LAPAI \\ MINNA-AGAI
}

\section{Objective}

The objective of the study was to apply linear programming model to optimally allocate the available buses of the Transport Authority to the service routes.

\section{The Problem Situation}


Niger State transport Authority (NSTA) operates ten intra and ten inter States routes transport service (see section 1.0). The authority has 80 , fourteen sitter buses (Fifty Hiace and thirty King Long Buses); from which six of the Hiace buses are usually on stand-by for emergency hire purposes. Twenty-five of the buses are used for city service, Civil servants and students Bus services within Minna municipal, Bida and Kontogora towns of the state. Forty-Nine are used for commuting the intra and inter states routes. According to findings, daily, the buses incur costs in four ways: fuel, percentage parking levy, routine service and maintenance (repair). Buses going to New-Busa, Mokwa, Ilorin and Lagos incur thrice the cost of repair (maintenance) due to bad road. The authority might want to turn from intuition and consider mathematically, an optimized way of allocating buses to routes in order to obtain daily optimal gain though there are seasonal variations in terms of passenger patronage during Christmas and Salla periods.

\section{Brief History of NSTA}

According to NSTA (n.d.), Niger State Transport Authority was established by the then Military Governor Col. Lawal Gwadabe on the $11^{\text {th }}$ August, 1988 under edict No. 11 of 1988 enacted by the State Government. A task force was immediately constituted, headed by a military administrator to oversee the affairs of the organization. Since inception, as argued by NSTA (n.d), the authority has become a household name and has lived up to expectation been the only viable transport venture in the state and one of the best in the country vis-à-vis its contemporaries.

NSTA has the following organizational chart:

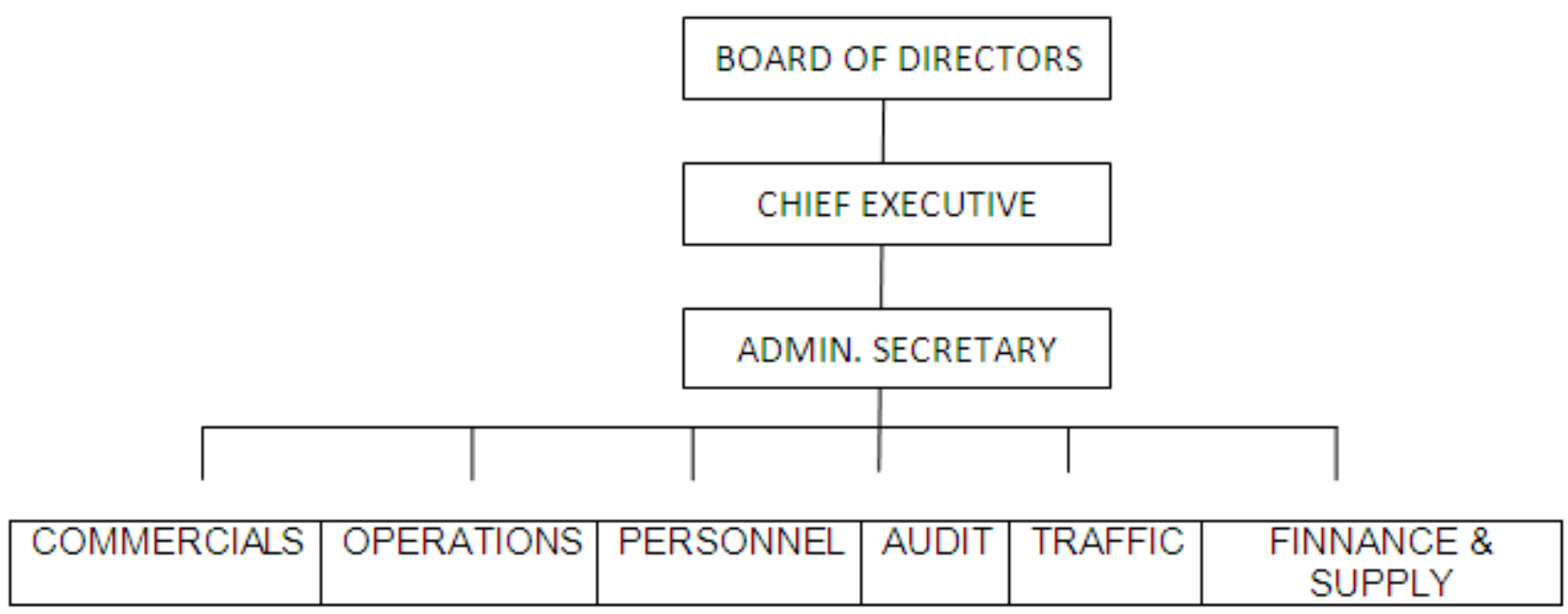

Source: NSTA (n.d), Niger State Transport Authority at a Glance, Yan Ju Prints, Minna, Nigeria

Figure 1. Organizational Chart of NSTA Minna 
The staff strength of NSTA currently stands at 206 under the Chief Executive/General Manager and Admin secretary being Alh. Umar Usman Nagogo and Alh. Ibrahim Barje Bawa respectively.

According to NSTA (n.d), Passengers are to note the following adherences:

i. The authority does not accept liability for loss of goods. Passengers are therefore advised to take good care of their goods/properties while waiting to board our vehicles and while on transit

ii. Preaching is strictly prohibited in our vehicles

iii. The habit of smoking in our vehicles is strictly prohibited

iv. You can only enter our vehicle when you have paid correct money and obtained a ticket for the journey

v. Tickets should be in passengers' possession until the end of the journey

vi. Ticket can only be issued to prospective commuters when they maintain a single queue

vii. Heavy loads, bags and boxes are paid for and tickets obtained before they are loaded in our vehicles

viii. Commuters are expected to present their tickets on demand to our traffic inspectors during the course of the journey when asked to do so

ix. Intentional damage to our vehicle seats, glasses etc. will not be accepted

x. Female passengers are seated at the back of the vehicle while male are seated at the front

xi. Hawking of goods inside our vehicles is strictly prohibited

xii. Passengers are to help us so that we can serve them better

\section{Brief Literature Review on Linear Programming}

Linear Programming (LP) is an optimal decision making tool in which the objective is a linear function and the constraints on the decision problem are linear equalities and/or inequalities. It is the most commonly applied form of constrained optimization. The four main elements of any constrained optimization are decision variables, objective function, constraints and variable bounds. In LP, all the mathematical expressions for the objective function and constraints are linear. One might imagine that the restriction to linear models severely limits the ability to model real-world problems; but this is not so. An amazing range of problems can be modeled using LP from airline scheduling to least cost petroleum processing and distribution (Chinneck, 2001; Ramsey, 2012)

The popular Simplex method of solving LP problems obtains the optimum solution by moving along edges of the solution space from one extreme point to another.

Linear programming problems have the property that the constraints and the objective function are all linear functions of the input variables. The existence of a polynomial time algorithm for solving linear programs and the multitude of optimization problems that they can encode makes them particularly useful in practice.

Generally, linear programming problem can be stated as follows:

Maximize the objective function

$$
\mathrm{Z}=\mathrm{c}_{1} \mathrm{x}_{1}+\mathrm{c}_{2} \mathrm{x}_{2}+\mathrm{c}_{3} \mathrm{x}_{3}+\ldots \ldots \ldots \ldots+\mathrm{c}_{\mathrm{n}} \mathrm{x}_{\mathrm{n}}
$$

Subject to the constraints

$$
\begin{aligned}
& a_{11} x_{1}+a_{12} x_{2}+\ldots \ldots \ldots \ldots \ldots \ldots+a_{1 n} x_{n 1} \\
& a_{21} x_{1}+a_{22} x_{2}+\ldots \ldots \ldots \ldots \ldots \ldots+a_{2 n} x_{n 2} \\
& a_{31} x_{1}+a_{32} x_{2}+\ldots \ldots \ldots \ldots \ldots \ldots .+a_{3 n} x_{n 3} \\
& \text {. } \\
& a_{m 1} x_{1}+a_{m 2} x_{2}+\ldots \ldots \ldots \ldots \ldots \ldots+a_{m n} x_{n m} \\
& x_{1} \geq 0 ; x_{2} \geq 0 \ldots . x_{n} \geq 0
\end{aligned}
$$

We can write the problem in abbreviated form called the standard form or canonical form as follows:

$$
\begin{array}{cc}
\text { Minimize } & \mathrm{C}^{\mathrm{T}} \mathrm{x} \\
\text { Subjectto } & \mathrm{Ax} \leq \mathrm{b} \\
\text { and } & \mathrm{x} \geq \mathrm{b}
\end{array}
$$

Here, $\mathrm{x}$ is a vector of real-valued variables (sometimes assumed to be non-negative), $\mathrm{C}$ and $\mathrm{b}$ are vectors of real constants, and $\mathrm{A}$ is a matrix of real constants.

\subsection{Definition of LP Terms}

1. Objective Function: The linear compilation of variables that must be minimized or maximized is called the objective function. It is a part of linear programming model that express what needs to be optimized depending on the objectives of the problem.

2. Decision Variables: They represent activity which is in competition with other variables for limited resources.

3. Constraints: These are different kinds of limitation to which the objective function is subjected. It is expressed in the form of linear inequalities or equalities depending on the sign used.

4. Slack Variables: They are the variables which are added to an inequality constraint to transform it to an equality constraints depending on the sign used. Slack variables cannot take on negative values.

5. Surplus Variables: They are variables which can be added to linear constraints. Consider inequality constraints of the sign " $\geq$ " i.e.

$$
\sum_{j=1}^{n} a_{i j x_{j}}=b_{j} ; \mathrm{I}=1,2, \ldots, \mathrm{m}
$$

Solution: - Any set $x_{j}$ which satisfies the constraints on the linear programming problem.

6. Basic Solution: A basic solution for a set of $m$ linear equation in $n$ variable is the solution in which $(n-m)$ variables are set equal to zero. 
7. Feasible Solution: A feasible solution to the linear programming problem is a vector.

8. Basic Feasible Solution: The basic feasible solution for a set of ' $m$ ' linear equation in $n$ variable is the solution in which the value of all variables is non-negative i.e. a basic solution which satisfies the non-negativity condition

9. Optimal Solution: An optimal solution is a feasible solution which optimizes the objective function or any point in the feasible region which gives the optimum value.

10. Optimal Value: This is the minimum or maximum value of an objective function to be calculated in a linear programming problem.

11. Feasible Region: The set of all possible solution.

12. Feasible Solution: Any point within and on the boundary of the feasible region are called feasible solution.

13. Non Degenerate Basic Feasible Solution: This is a basic feasible solution which has exactly $m$ positive $x_{i}$ i.e. all basic variables are positive.

14. An Augmented solution: Is a solution for a problem that was originally in inequality form that has been augmented by the corresponding values of the slack or surplus variables to change the problem into equality form (Hillier and Lieberman, 1986).

\subsection{Advantages of LP}

1. Linear programming helps in dealing with the problem of allocation of limited resources among different competitive activities in the most optimal manner.

2. It is concerned with determining the optimal allocation of scarce resources to meet certain objectives.

3. It provides practical and better quality of decision that reflects very precisely the limitations of the system. I.e. various restrictions under which the system must operate for the solution to be optimal.

4. Linear programming is an adaptive and flexible mathematical technique and hence can be used in analyzing a variety of multi-dimensional problem quite successfully.

5. The minimization of a function is equal to the maximization of the negative of that same function. i.e.

$$
\mathrm{P}_{\min }=0=-\mathrm{P}_{\max }
$$

6. The techniques help to make the best possible use of available productive resources.

7. Linear programming is applicable to transportation problem, diet problem, product mix problems, investment planning problem, marketing and distribution management etc.

8. According to Adler et al (1995), linear programs are expressed in an inequality form, which allows for the inexact computation of the algorithms direction of improvement, resulting in a significant computational advantage.

\subsection{Disadvantages of $L P$}

1. Linear programming is applicable only to problem where the constraints and the objective functions are linear.

2. Factors such as uncertainty, weather conditions etc. are not taken into consideration.

3. There is restriction to linear objective function.

4. Reducing problems to a set of linear equation is usually very difficult.

\section{Raw Data Collected}

The data below were collected in December, 2012 from NSTA headquarters which is located at Shango by Paiko Road, Opposite Trade Fair Complex, Minna. Data on bus routes were obtained from the Interview with the desk officer, Mal. Babangida; while that of bus service and maintenance were obtained from the interview with the Assistant Workshop Manager, Mal. Ali Baba Suleiman. 
Table 1. Data on Bus Routes

\begin{tabular}{|c|c|c|c|c|c|c|c|c|}
\hline $\mathrm{S} / \mathrm{N}$ & Route & $\begin{array}{c}\text { Frequency Of Trips Per } \\
\text { Week }\end{array}$ & $\begin{array}{c}\text { Fuel } \\
\text { Consumption } \\
\text { (Ltrs) }\end{array}$ & $\begin{array}{l}\text { Percentage } \\
\text { Parking } \\
\text { Levy }\end{array}$ & $\begin{array}{c}\text { No. Of } \\
\text { Buses Per } \\
\text { Route Per } \\
\text { Day }\end{array}$ & $\begin{array}{l}\text { Max No. } \\
\text { Of Trips } \\
\text { Per Bus } \\
\text { Per Day }\end{array}$ & $\begin{array}{l}\text { No. Of } \\
\text { Hours } \\
\text { Per Half } \\
\text { Trip }\end{array}$ & $\begin{array}{c}\text { Transport } \\
\text { Fare Per } \\
\text { Person }\end{array}$ \\
\hline 1 & MINNA-ILORIN & DAILY & 125 & NIL & 2 & 1 & 6 & 1,700 \\
\hline 2 & MINNA-LAGOS & ” & 195 & 10 & 3 & 1 & 10 & 3,500 \\
\hline 3 & MINNA-KADUNA & " & 85 & 7 & 2 & 1 & 3 & 800 \\
\hline 4 & MINNA-KANO & TURN BY TURN & 155 & NIL & 4 & 1 & 6 & 1,500 \\
\hline 5 & MINNA-MAKURDI & DAILY & 145 & $"$ & 1 & 1 & 6 & 2,000 \\
\hline 6 & MINNA-JOS & , & 125 & 7 & 1 & 1 & 6 & 2,000 \\
\hline 7 & MINNA-BAUCHI & 2 TIMES PER WEEK & 155 & 7 & 1 & 1 & 7 & 2,200 \\
\hline 8 & MINNA-SOKOTO & TURN BY TURN & 185 & 7 & 1 & 1 & 9 & 2,500 \\
\hline 9 & MINNA-ZAMFARA & ONCE A WEEK & 125 & NIL & 1 & 1 & 6 & 1,800 \\
\hline 10 & MINNA-KATSINA & TURN BY TURN & 155 & " & 1 & 1 & 7 & 2,000 \\
\hline 11 & MINNA-BIDA & DAILY & 30 & , & 3 & 3 & 1 & 300 \\
\hline 12 & MINNA-MOKWA & " & 75 & , & 2 & 1 & 3 & 900 \\
\hline 13 & MINNA-N/BUSA & 3 TIMES A WEEK & 85 & , & 1 & 1 & 4 & 1,200 \\
\hline 14 & MINNA-KTAGORA & DAILY & 60 & ” & 2 & 1 & 2 & 600 \\
\hline 15 & MINNA-KAGARA & , & 30 & " & 1 & 2 & 1.5 & 300 \\
\hline 16 & MINNA-W/SHISHI & $"$ & 25 & $"$ & 1 & 3 & 1 & 150 \\
\hline 17 & MINNA-SULEJA & ” & 30 & ” & 3 & 2 & 1.5 & 350 \\
\hline 18 & MINNA-S/PAWA & " & 30 & $"$ & 1 & 2 & 1 & 300 \\
\hline 19 & MINNA-LAPAI & , & 25 & $"$ & 1 & 2 & 1 & 150 \\
\hline 20 & MINNA-AGAI & , & 30 & " & 1 & 1 & 1.5 & 200 \\
\hline & TOTAL & & 1870 & 38 & 33 & 28 & 83.5 & 24450 \\
\hline
\end{tabular}

Explaining Table 1:

Route: This column shows all the ten (10) inter and ten (10) intra States routes that NSTA buses ply.

Frequency of Trips per Week: This is the number of times a bus ply a particular route in a week. Note that, a trip means to and fro the destination. For example, Minna-Ilorin trip means the bus has gone from Minna to Ilorin and back. A bus that has gone from Minna to Ilorin only has made half trip. Fuel Consumption in Liters: This is the number of liters of fuel consumed by one bus per trip. The fuel is given to bus drivers for a whole trip fiscally.

Percentage Parking Levy: This is a levy paid by NSTA for parking space to authorities of garages in towns where NSTA does not have its own facility or staff. The levy is an agreed percentage of the bus capacity per night.

Number of Buses per Route per Day: This is the number of buses that NSTA currently allocates to ply a particular route per day

Maximum Number of Trips per Bus per Day: This is the maximum number of times that a bus can possibly make a 'to-and-fro' journey in a day. For example, one bus can make two or more trips from Minna to Bida in a day. Note that, a bus that unavoidably makes only half trip from Minna to a destination, say Lagos, in a day is completed by another bus from that same destination (Lagos) back to Minna

Number of Hours per Half Trip: This is the number of hours a bus spends on the road under normal conditions from Minna.

Transport Fare per person: This is the cost charged per passenger from Minna to a destination. Usually, it is the same cost charged per passenger from that same destination back to Minna. 
Table 2. Data on Bus Service

\begin{tabular}{|c|c|c|}
\hline S/N & Required Service Items & Amount $(\mathrm{N})$ \\
\hline 1 & Oil filter & 500 \\
\hline 2 & 5-litre Engine oil & 2800 \\
\hline 3 & Oil treatment & 400 \\
\hline & Total & 3700 \\
\hline
\end{tabular}

Note: Buses in NSTA are serviced twice a month, which is after 15 days.

Table 3. Data on Bus Repair/Maintenance

\begin{tabular}{|c|c|c|c|}
\hline $\mathrm{S} / \mathrm{N}$ & Repair/Maintenance Items & Cost $(\mathrm{N})$ & Duration it lasts \\
\hline 1 & Tyre & 25000 & 3 months \\
\hline 2 & Front bearing & 5000 & 6 months \\
\hline 3 & Break disk & 12000 & 2 years \\
\hline 4 & Break pad & 1000 & 2 weeks \\
\hline 5 & Break lining & 2400 & 1 month \\
\hline 6 & Car battery & 11000 & 2 years \\
\hline 7 & Shocks filling & 1000 & 4 months \\
\hline 8 & Sparking plugs & 4000 & 2 years \\
\hline 9 & Fuel pump & 5000 & 2 years \\
\hline 10 & Release bearing & 2000 & 2 years \\
\hline & Total & 68400 & \\
\hline
\end{tabular}

Note: Buses going to New-Busa, Mokwa, Ilorin and Lagos incur thrice the cost of repair/maintenance due to bad road.

\section{Data Analysis}

Table 4. Daily cost of Bus Service

\begin{tabular}{|c|c|c|c|c|}
\hline $\mathrm{S} / \mathrm{N}$ & $\begin{array}{c}\text { Required Service } \\
\text { Items }\end{array}$ & $\begin{array}{c}\text { Amount } \\
\text { Per 15 Days (N) }\end{array}$ & $\begin{array}{c}\text { Amount } \\
\text { Per month (N) }\end{array}$ & $\begin{array}{c}\text { Daily service } \\
\text { cost per bus (N) }\end{array}$ \\
\hline 1 & Oil filter & 500 & 1000 & $1000 \div 30=33.3$ \\
\hline 2 & 5 -litre Engine oil & 2800 & 5600 & $5600 \div 30=186.7$ \\
\hline 3 & Oil treatment & 400 & 800 & $800 \div 30=26.7$ \\
\hline & Total & 3700 & 7400 & $\Omega^{247}$ \\
\hline
\end{tabular}

Note: Buses in NSTA are serviced twice a month, which is after 15 days. This means that a bus in NSTA consumes N7400 in a month (Amount per 15 Days $\times 2$ ). Dividing service amount per month by 30 days gives us N247 as the cost of servicing a bus in a day.

Table 5. Daily Cost of Bus Repair/Maintenance

\begin{tabular}{|c|c|c|c|c|c|}
\hline $\mathrm{S} / \mathrm{N}$ & Repair/Maintenance Items & Cost $(\mathrm{N})$ & Duration it lasts & Duration in days & Cost per Day (N) \\
\hline 1 & Tyre & 25000 & 3 months & $3 \times 30=90$ & 278 \\
\hline 2 & Front bearing & 5000 & 6 months & $6 \times 30=180$ & 28 \\
\hline 3 & Break disk & 12000 & 2 years & $2 \times 12 \times 30=720$ & 17 \\
\hline 4 & Break pad & 1000 & 2 weeks & $2 \times 7=14$ & 71 \\
\hline 5 & Break lining & 2400 & 1 month & $1 \times 30=30$ & 15 \\
\hline 6 & Car battery & 11000 & 2 years & $2 \times 12 \times 30=720$ & 80 \\
\hline 7 & Shocks filling & 1000 & 4 months & $4 \times 30=120$ & 08 \\
\hline 8 & Sparking plugs & 4000 & 2 years & $2 \times 12 \times 30=720$ & 06 \\
\hline 9 & Fuel pump & 5000 & 2 years & $2 \times 12 \times 30=720$ & 07 \\
\hline 10 & Release bearing & 2000 & 2 years & $2 \times 12 \times 30=720$ & 03 \\
\hline & Total & 68400 & & & 513 \\
\hline
\end{tabular}

Note: The cost of maintaining a bus in a day is calculated to be N513 (Cost $\div$ Duration in Days). Since buses going to New-Busa, Mokwa, Ilorin and Lagos incur thrice the cost due to bad road, their repair/maintenance costs will be $513 \times 3=\mathrm{N} 1539$ per bus per day. 
Table 6. Daily Contribution per Bus

\begin{tabular}{|c|c|c|c|c|c|c|c|c|c|c|c|c|c|}
\hline $\begin{array}{c}\text { Fuel } \\
\text { Consumptio } \\
\text { n Per Bus } \\
\text { (Ltrs) }\end{array}$ & $\begin{array}{c}\text { Fuel } \\
\text { Consumptio } \\
\text { n Per Bus } \\
\text { (N) }\end{array}$ & $\begin{array}{l}\text { Percentage } \\
\text { Parking } \\
\text { Levy Per } \\
\text { Bus (\%) }\end{array}$ & $\begin{array}{c}\text { Moneytary } \\
\text { Parking } \\
\text { Levy (N) }\end{array}$ & $\begin{array}{c}\text { Number Of } \\
\text { Buses Per } \\
\text { Route Per } \\
\text { Day }\end{array}$ & $\begin{array}{c}\text { Max No. Of } \\
\text { Trips Per } \\
\text { Bus Per } \\
\text { Day }\end{array}$ & $\begin{array}{l}\text { Equivelent } \\
\text { No. Of } \\
\text { Buses Per } \\
\text { Route Per } \\
\text { Day }\end{array}$ & $\begin{array}{l}\text { No. Of } \\
\text { Hours Per } \\
\text { Half Trip }\end{array}$ & $\begin{array}{l}\text { Transport } \\
\text { Fare Per } \\
\text { Person }\end{array}$ & $\begin{array}{c}\text { Daily Cost } \\
\text { Of A Bus } \\
\text { Service }\end{array}$ & $\begin{array}{l}\text { Daily Cost } \\
\text { Of A Bus } \\
\text { Repair/ } \\
\text { Maintenanc } \\
\text { e (N) }\end{array}$ & $\begin{array}{l}\text { Return Per } \\
\text { Bus Per Trip } \\
\text { (N) }\end{array}$ & $\begin{array}{l}\text { Daily Total } \\
\text { Expenditure } \\
\text { Per Bus } \\
\text { (N) }\end{array}$ & $\begin{array}{c}\text { Daily } \\
\text { Contribution } \\
\text { Per Bus } \\
\text { (N) }\end{array}$ \\
\hline 125 & 15,000 & NIL & 0 & 2 & 1 & 2 & 6 & 1,700 & 247 & 1,539 & 47600 & 16786 & 30814 \\
\hline 195 & 23,400 & 10 & 4,900 & 3 & 1 & 3 & 10 & 3,500 & 247 & 1,539 & 98000 & 30086 & 67914 \\
\hline 85 & 10,200 & 7 & 780 & 4 & 1 & 2 & 3 & 800 & 247 & 513 & 22400 & 11740 & 10660 \\
\hline 155 & 18,600 & NIL & 0 & 4 & 1 & 4 & 6 & 1,500 & 247 & 513 & 42000 & 19360 & 22640 \\
\hline 145 & 17,400 & , & 0 & 1 & 1 & 1 & 6 & 2,000 & 247 & 513 & 56000 & 18160 & 37840 \\
\hline 125 & 15,000 & 7 & 1960 & 1 & 1 & 1 & 6 & 2,000 & 247 & 513 & 56000 & 17720 & 38280 \\
\hline 155 & 18,600 & 7 & 2156 & 1 & 1 & 1 & 7 & 2,200 & 247 & 513 & 61600 & 21516 & 40084 \\
\hline 185 & 22,200 & 7 & 2450 & 1 & 1 & 1 & 9 & 2,500 & 247 & 513 & 70000 & 25410 & 44590 \\
\hline 125 & 15,000 & NIL & 0 & 1 & 1 & 1 & 6 & 1,800 & 247 & 513 & 50400 & 15760 & 34640 \\
\hline 155 & 18,600 &, & 0 & 1 & 1 & 1 & 7 & 2,000 & 247 & 513 & 56000 & 19360 & 36640 \\
\hline 30 & 3,600 &, & 0 & 3 & 3 & 9 & 1 & 300 & 247 & 513 & 8400 & 4360 & 4040 \\
\hline 75 & 9,000 & $"$ & 0 & 2 & 1 & 2 & 3 & 900 & 247 & 1,539 & 25200 & 10786 & 14414 \\
\hline 85 & 10,200 & $"$ & 0 & 1 & 1 & 1 & 4 & 1,200 & 247 & 1,539 & 33600 & 11986 & 21614 \\
\hline 60 & 7,200 & $"$ & 0 & 2 & 1 & 2 & 2 & 600 & 247 & 513 & 16800 & 7960 & 8840 \\
\hline 30 & 3,600 & , & 0 & 1 & 2 & 2 & 1.5 & 300 & 247 & 513 & 8400 & 4360 & 4040 \\
\hline 25 & 3,000 & $"$ & 0 & 1 & 3 & 3 & 1 & 150 & 247 & 513 & 4200 & 3760 & 440 \\
\hline 30 & 3,600 & $"$ & 0 & 3 & 2 & 6 & 1.5 & 350 & 247 & 513 & 9800 & 4360 & 5440 \\
\hline 30 & 3,600 & 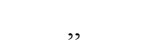 & 0 & 1 & 2 & 2 & 1 & 300 & 247 & 513 & 8400 & 4360 & 4040 \\
\hline 25 & 3,000 &, & 0 & 1 & 2 & 2 & 1 & 150 & 247 & 513 & 4200 & 3760 & 440 \\
\hline 30 & 3,600 & $"$ & 0 & 1 & 1 & 1 & 1.5 & 200 & 247 & 513 & 5600 & 4360 & 1240 \\
\hline 1870 & 224400 & 38 & 12246 & 35 & 28 & 47 & 83.5 & 24450 & 4940 & 14364 & 684600 & 255950 & 428650 \\
\hline
\end{tabular}

- 'Daily cost of service per bus' and 'daily cost of repair/maintenance per bus' are obtained in tables 4 and 5 respectively.

- 'Equivalent number of buses per route' is obtained by multiplying 'Number of buses per route' by 'number of trips per day'. Remember, a trip means to and fro minna.

- 'Return per bus per trip' is obtained by multiplying 'transport fare' per passenger by 2 (since a trip means to and fro) and 14 (number of passengers in a bus)

- 'Total expenditure per bus' is obtained by adding 'fuel consumption', Monetary parking levy', 'daily service per bus' and 'daily repair/maintenance per bus'.

- 'Daily contribution per bus' is obtained by subtracting 'total expenditure' from 'return per bus' 
Table 7. Daily Contribution per Route

\begin{tabular}{|c|c|c|}
\hline $\mathrm{S} / \mathrm{N}$ & Route & $\begin{array}{c}\text { Moneytary } \\
\text { Parking Levy Pe } \\
\text { Route }\end{array}$ \\
\hline 1 & MINNA-ILORIN & 0 \\
\hline 2 & MINNA-LAGOS & 14700 \\
\hline 3 & MINNA-KADUNA & 1560 \\
\hline 4 & MINNA-KANO & 0 \\
\hline 5 & MINNA-MAKURDI & 0 \\
\hline 6 & MINNA-JOS & 1960 \\
\hline 7 & MINNA-BAUCHI & 2156 \\
\hline 8 & MINNA-SOKOTO & 2450 \\
\hline 9 & MINNA-ZAMFARA & 0 \\
\hline 10 & MINNA-KATSINA & 0 \\
\hline 11 & MINNA-BIDA & 0 \\
\hline 12 & MINNA-MOKWA & 0 \\
\hline 13 & MINNA-N/BUSA & 0 \\
\hline 14 & MINNA-KTAGORA & 0 \\
\hline 15 & MINNA-KAGARA & 0 \\
\hline 16 & MINNA-W/SHISHI & 0 \\
\hline 17 & MINNA-SULEJA & 0 \\
\hline 18 & MINNA-S/PAWA & 0 \\
\hline 19 & MINNA-LAPAI & 0 \\
\hline 20 & MINNA-AGAI & 0 \\
\hline & TOTAL & 22826 \\
\hline
\end{tabular}

Equivelent No Of
Buses Per Route
Per Day
2
3
2
4
1
1
1
1
1
1
9
2
1
2
2
3
6
2
2
1
47

$\begin{array}{ccc}\begin{array}{c}\text { Fuel Consumption } \\ \text { Per Route }(\mathrm{N})\end{array} & \begin{array}{c}\text { Transport } \\ \text { Fare Per } \\ \text { Person }\end{array} & \begin{array}{c}\text { Daily Cost Of } \\ \text { Bus Service } \\ \text { Per Route }\end{array} \\ 30000 & 1,700 & 494 \\ 70200 & 3,500 & 741 \\ 20400 & 800 & 494 \\ 74400 & 1,500 & 988 \\ 17400 & 2,000 & 247 \\ 15000 & 2,000 & 247 \\ 18600 & 2,200 & 247 \\ 22200 & 2,500 & 247 \\ 15000 & 1,800 & 247 \\ 18600 & 2,000 & 247 \\ 32400 & 300 & 2223 \\ 18000 & 900 & 494 \\ 10200 & 1,200 & 247 \\ 14400 & 600 & 494 \\ 7200 & 300 & 494 \\ 9000 & 150 & 741 \\ 21600 & 350 & 1482 \\ 7200 & 300 & 494 \\ 6000 & 150 & 494 \\ 3600 & 200 & 247 \\ 431400 & 24450 & 232180\end{array}$

Daily Cost Of Bus
Repair/ Maintenance
Per Route (N)
3078
4617
1026
2052
513
513
513
513
513
513
4617
3078
1539
1026
1026
1539
3078
1026
1026
513
675108

$\begin{array}{cc}\text { Return Per } & \begin{array}{c}\text { Daily Total } \\ \text { Expenditure Per } \\ \text { Route (N) }\end{array} \\ 95200 & 33572 \\ 294000 & 90258 \\ 44800 & 23480 \\ 168000 & 77440 \\ 56000 & 18160 \\ 56000 & 17720 \\ 61600 & 21516 \\ 70000 & 25410 \\ 50400 & 15760 \\ 56000 & 19360 \\ 75600 & 39240 \\ 50400 & 21572 \\ 33600 & 11986 \\ 33600 & 15920 \\ 16800 & 8720 \\ 12600 & 11280 \\ 58800 & 26160 \\ 16800 & 8720 \\ 8400 & 7520 \\ 5600 & 4360 \\ 1264200 & 498154 \\ & \end{array}$

Daily Contribution Per Route $(\mathrm{N})$

61628

203742

21320

90560

37840

38280

40084

44590

34640

36640

36360

28828

21614

17680

8080

1320

32640

8080

880

1240

766046

- 'Monetary parking levy per route' is obtained by multiplying 'Monetary parking levy per bus' by 'Equivalent number of buses per route'

- 'Fuel consumption per route' is obtained by multiplying 'Fuel consumption per bus' by 'Equivalent number of buses per route'

- 'Daily cost of service per route' is obtained by multiplying 'Daily cost of service per bus' by 'Equivalent number of buses per route'

- 'Daily cost of repair/maintenance per route; is obtained by multiplying 'Daily cost of repair/maintenance per bus' and 'Equivalent number of buses per route'

- 'Return per route' is obtained by multiplying 'Return per bus' and 'Equivalent number of buses per route'

- 'Total expenditure per route' is obtained by adding 'fuel consumption per route', Monetary parking levy per route', 'Daily cost of service per route' and 'Daily cost of repair/maintenance per route'.

- 'Daily contribution per route' is obtained by subtracting 'total expenditure per route' from 'Return per route' 


\section{NSTA Problem Formulation}

The Problem Formulation is based on the information under the Problem Situation and Table 6. The problem is formulated under the assumption that all the 49 buses that commute intra and inter states routes are working daily.

Based on the interview with NSTA, availability of passengers and the number of other transport services plying the same routes, among other factors, determine the number of buses that NSTA can assign to these routes. The following shows the possible number of buses that can be scheduled to routes:

$\begin{array}{cc}\text { Inter States Routes Possible No of Buses } & \\ \text { MINNA-ILORIN } & 2-3 \\ \text { MINNA-LAGOS } & 3-4 \\ \text { MINNA-KADUNA } & 2-4 \\ \text { MINNA-KANO } & 3-5 \\ \text { MINNA-MAKURDI } & 1 \\ \text { MINNA-JOS } & 1 \\ \text { MINNA-BAUCHI } & 1\end{array}$

$\begin{array}{cc}\text { MINNA-SOKOTO } & 1 \\ \text { MINNA-ZAMFARA } & 1 \\ \text { MINNA-KATSINA } & 1 \\ \text { Intra State Routes Possible No of Buses } & \\ \text { MINNA-BIDA } & 9 \\ \text { MINNA-MOKWA } & 1-2 \\ \text { MINNA-NEW BUSA } & 1-2 \\ \text { MINNA-KTAGORA } & 2-3 \\ \text { MINNA-KAGARA } & 2-4 \\ \text { MINNA-WUSHISHI } & 1-2 \\ \text { MINNA-SULEJA } & 6 \\ \text { MINNA-SERKI PAWA } & 1-2 \\ \text { MINNA-LAPAI } & 0-1 \\ \text { MINNA-AGAI } & 0-1\end{array}$

It must be strongly noted that our allocation must not exceed 49 buses available for intra and inter states services

Below is our problem formulation:

$67914 \times 2+10660 \times 3+22640 \times 4+37840 \times 5+38280 \times 6+40084 \times 7+44590 \times 8+34640 \times 9+36640 \times 10+4040 \times 11+14414 \times 12+21614 \times 13+8840 \times 14+4040 \times 15+440 \times 16+5440 \times 17+4040 \times 18+440 \times 19+1240 \times 20$

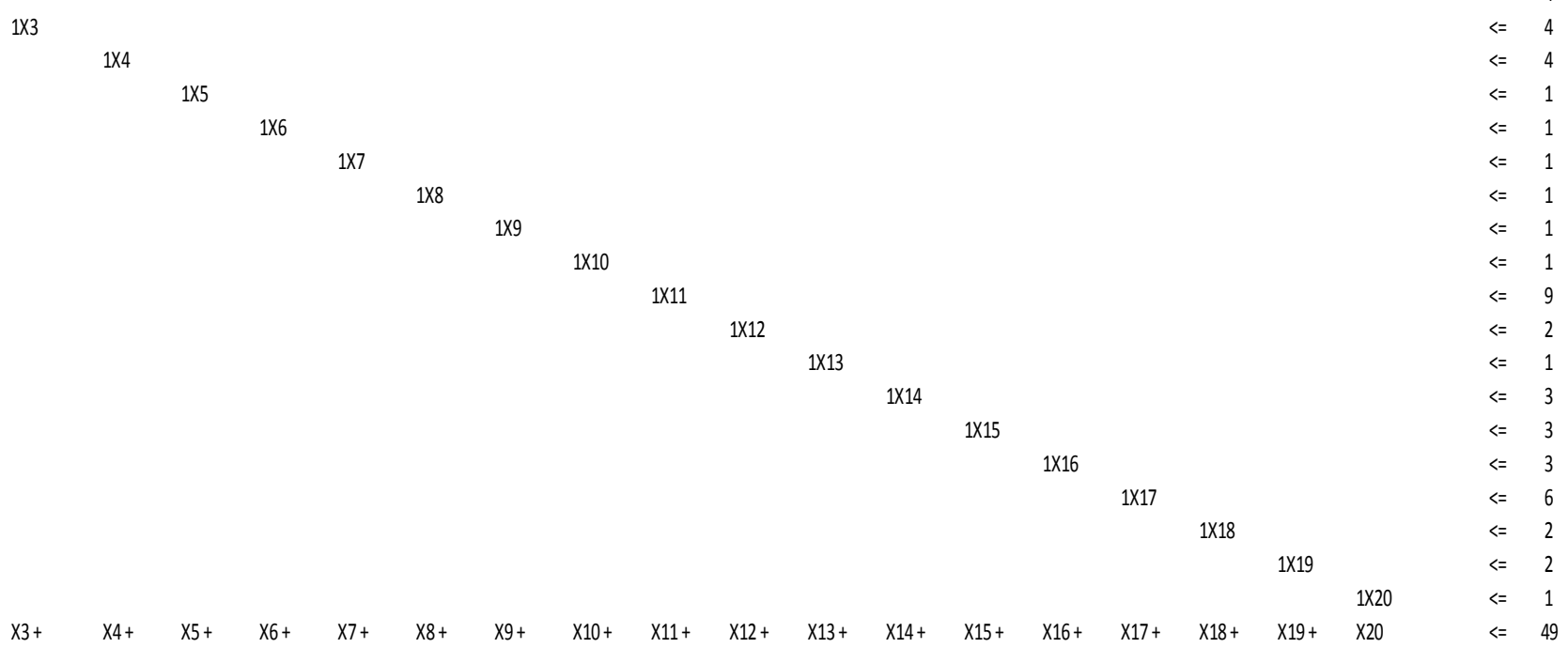

\section{Result of the Problem Formulation}

The formulated problem was solved using TORA - computer software used in solving Linear Programming which has been developed by Hamdy Taha (2002 edition). The $20^{\text {th }}$ iteration reached the optimal solution and the objective value of 897 , 214 is obtained as can be seen on TORA window under figure 2 below 
TORA C:IUsers\-IDocuments\NSTA NEW.txt

LINEAR PROGRAMMING

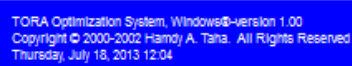

\begin{tabular}{|l|l|l|}
\hline & 回 & $\mathbf{x}$ \\
\hline
\end{tabular}

Title: NSTA PROBLEM

Final Iteration No.: 20

Objective Value (Max) $=897214.0$-. Alternative solution(s) detected (enter ITERATIONS mode to determine such solutions)

\begin{tabular}{llllll} 
& & Next Iteration & All Iterations & Write to Printer \\
\hline Variable & Value & Obj Coeff & Obj Val
\end{tabular}

\begin{tabular}{lrrr}
\hline Variable & Value & Obj Coeff & Obj Val Contrib \\
\hline x1: MINNA-ILORIN & 3.0 & 30814.0 & 92442.0
\end{tabular}

x1: MINNA-ILORII

$x 2$ : MINNA-LAGOS

$x 3$ : MINNA-KADUNA

X: MINNA-KANO

x5: MINNA-MAKURD

$x 6$ : MINNA-JOS

7: MINNA-BAUCHI

$\mathrm{x} 8$ : MINNA-SOKOTO

$x 9$ : MINNA-ZAMFAR

x10: MINNA-KATSIN

$x 11$ : MINNA-BIDA

x12: MINNA-MOKWA

$x$ 13: MINNA-N/BUSA

x14: MINNA-KTAGOR

x15: MINNA-KAGARA

$x 16$ : MINNA-W/SHIS

x17: MINNA-SULEJA

$x$ 18: MINNA-S/PAWA

x19: MINNA-LAPAI

x20: MINNA-AGAI

Constraint

3.0
4.0

4.0
4.0
4.0

4.0
1.0

1.0
1.0
1.0

1.0

1.0

1.0
1.0
1.0

1.0

9.0

2.0

1.0

3.0

3.0

1.0

6.0

2.0

0.0

$1(<) \quad 3.0$

$2(<)$

30814.0

67914.0

10660.0

22640.0

37840.0

38280.0

40084.0

44590.0

34640.0

36640.0

4040.0

14414.0

21614.0

8840.0

4040.0

440.0

5440.0

4040.0

440.0

1240.0

Slack-/Surplus+

$3.0 \quad 0.0$

0.0
0.0

271656.0

271656.0
42640.0

90560.0

37840.0

38280.0

40084.0

44590.0

34640.0

36640.0

36360.0

28828.0

21614.0

26520.0

12120.0

440.0

32640.0

8080.0

0.0
1240.0

10

Figure 2. Linear Programming Output Summary

Explanation

From figure 2 above, variable is the name of the route. For example, x1 represents Minna to Ilorin route. Value is the number of buses to be allowed to ply Minna-Ilorin. Objective coefficient is the contribution made per bus. Objective value contribution is the result of multiplying 'value' and the 'objective coefficient' 


\section{Recommendation}

Table 8 below shows the summary of our recommendation which is based on the result of our study:

Table 8. Recommended Schedule

\begin{tabular}{|c|c|c|c|}
\hline S/No & Route & $\begin{array}{c}\text { NSTA Current } \\
\text { Schedule }\end{array}$ & $\begin{array}{c}\text { Recommended } \\
\text { Schedule }\end{array}$ \\
\hline 1 & MINNA-ILORIN & 2 & 3 \\
\hline 2 & MINNA-LAGOS & 3 & 4 \\
\hline 3 & MINNA-KADUNA & 2 & 4 \\
\hline 4 & MINNA-KANO & 4 & 4 \\
\hline 5 & MINNA-MAKURDI & 1 & 1 \\
\hline 6 & MINNA-JOS & 1 & 1 \\
\hline 7 & MINNA-BAUCHI & 1 & 1 \\
\hline 8 & MINNA-SOKOTO & 1 & 1 \\
\hline 9 & MINNA-ZAMFARA & 1 & 1 \\
\hline 10 & MINNA-KATSINA & 1 & 1 \\
\hline 11 & MINNA-BIDA & 9 & 9 \\
\hline 12 & MINNA-MOKWA & 2 & 2 \\
\hline 13 & MINNA-N/BUSA & 1 & 1 \\
\hline 14 & MINNA-KTAGORA & 2 & 3 \\
\hline 15 & MINNA-KAGARA & 2 & 3 \\
\hline 16 & MINNA-W/SHISHI & 3 & 1 \\
\hline 17 & MINNA-SULEJA & 6 & 6 \\
\hline 18 & MINNA-S/PAWA & 2 & 2 \\
\hline 19 & MINNA-LAPAI & 2 & 0 \\
\hline 20 & MINNA-AGAI & 1 & 1 \\
\hline
\end{tabular}

Note: From S/NO 1 in Table 8 above, the current NSTA bus schedule from Minna to Ilorin is 2 buses per day, while our model recommends 3 buses from Minna to Ilorin per day. This is the same procedure down to S/NO 20

\section{Conclusion}

The current NSTA schedule seen in Table 8 yields a daily contribution of N766, 046 (see Table7). Our recommended schedule will yield N897, 214 when implemented. This means that our model is better by yielding additional N131, 168 to the organization.

\section{REFERENCES}

[1] Adler I., Karmarkar N, Mauricio G.C. and Veiga G.(1995), An Implementation of Karmarkar's Algorithm for Linear Programming. Retrieved from http://citeseerx.ist.psu.edu/vie wdoc/download?doi $=10: 1: 1: 48: 8163 \mathrm{rep}=$ rep1 type $=$ pdf

[2] Chinnech J.W. (2001), Practical Optimization; A Gentle Introduction. Retrieved from http://www.sce.carleton.ca/facu lty/Chinneck/po.html

[3] Hillier F.S and Lieberman G.J (1986), Introduction to operations research. Holden-day, Inc. USA

[4] NSTA (n.d), Niger State Transport Authority at a Glance, Yan Ju Prints, Minna, Nigeria

[5] Ramsey D. (2012), Operations Research I. Retrieved from

[6] http://www3.ul.ie/ramsey/Lectures/OperationsResearch1=or 1slides $3: p d f$

[7] Taha H.A.(2002), TORA Optimization System. Prentice-hall, Inc. London 